\title{
National and cultural semantics of Russian anthropometaphors
}

\author{
Elena Nikolaevna Denisenko* \\ Diplomatic Academy of the Ministry of Foreign Affairs of the Russian Federation, Department of \\ Russian and other Slavic Languages, Moscow, Russia
}

\begin{abstract}
The article belongs to the field of cognitive-oriented research and examines the role of humans in language and culture and the need to study their close relationships. Each culture generates certain types of anthropometaphors, and each such nomination reflects the elements of this culture. Lexical units in a figurative sense, being "universals of consciousness", can have vivid national and cultural markings or function as globally precedent names. Anthropometaphors are an important source of not only linguistic but also historical and cultural knowledge. The article provides examples of the deconstruction of anthroponyms, filling them with the expressiveness of the appellative, and indicates the main factors in their rethinking.
\end{abstract}

Keywords: anthropometaphor, appellative, anthroponym, national-cultural connotation, linguoculture

\section{Introduction}

Despite numerous studies, the metaphor is of constant interest to scientists - literary scholars, linguists, ethnolinguists, psychologists, etc. In modern metaphorology, the cognitive approach proposed by Lakoff and Johnson occupies a leading position [1]. The classical theory of cognitive metaphors, the theory of primary and complex metaphors, the connective theory of metaphorical interpretation, the theory of metaphorical modeling, the theory of conceptual integration, etc. are developing cognitive and conceptual metaphorology within the framework of the cognitive direction, which also explores the national and cultural semantics of metaphors.

The cognition of the world and the development of a linguistic personality through the study of national and cultural specifics take place, among other things, based on an analysis of metaphorical formations. According to Maslova: "It has been proved that metaphors are universals of consciousness, modern psychologists tend to associate the metaphorical vision of the world with the genesis of humans and, accordingly, human culture" [2].

A metaphor is inherently anthropometric. It compares different contents, moral and bodily essences, comparing them with a specific or abstract personality. The correlation is based on the measure of human cognition of the world, on the breadth and depth of mental

${ }^{*}$ Corresponding author: $\underline{\text { olenaden@gmail.com }}$ 
knowledge and sensory representation, on the system of cultural and national values. Stable metaphorical formations go through a long period of development, conserving in themselves cultural and linguistic information: they are reflecting the peculiarities of the historical development of the language, the specificity of culture, and the mentality of a certain linguocultural community.

\section{Methods}

The methodology is complex and is represented by descriptive and analytical methods.

To analyze Russian anthropometaphors, this work uses a complex method of linguistic research, in particular, the method of describing the cultural component, including the analysis of dictionary definitions. Taking into account the linguocultural paradigm and national characteristics of the Russian language and culture made it possible to more fully present a fragment of the Russian linguistic picture of the world.

\section{$3 \quad$ Results}

Metaphors are the main way of forming the meaning of a person's naming, which arose on the basis of the appeal of anthroponyms. Vivid examples of Russian secondary names with national-cultural semantics are the eponyms of khlestakov, oblomov, emelya, etc.

One of the main factors in the rethinking of an anthroponym is the historical and literary-figurative significance of this anthroponym, its cultural and social meaning [3].

\section{Discussion}

The deconstruction of an anthroponym, its filling with the expressiveness of the appellative is determined by the time of its most active functioning, significance, phonetic consonance, etc. So the names of literary heroes, specific historical figures are often subjected to metaphorical transfer. In the Russian language, metaphors have a cultural connotation - the names of the heroes of national literature, often having the status of precedent names: mitrofanushka, pechorin, oblomov, shvonder, stirlitz, bender, etc. The use in the figurative sense of Gogol's anthroponyms khlestakov, nozdrev, molchalin, skalozub, manilov, plyushkin, etc., has become firmly established. The names of the characters are also used as an expressive means of figurative speech. Metaphors - the names of the heroes of foreign literature used in Russian speech have a universal meaning and do not carry a national cultural connotation, which means that they are globally precedent names: don juan, othello, mephistopheles, hamlet, tartuffe, robinson, falstaff, munchausen, lovelace, quasimodo, montecristo/monte cristo, etc. [4].

The names of historical persons - well-known public and political figures, scientists, writers - are given a nominal meaning. Some of the metaphorical names - precedent names - have a pronounced national cultural connotation: mamai, susanin, chapaev, lomonosov, lje dmitry, rasputin, stalin, etc. The same way others like casanova, napoleon, croesus, rockefeller, philanthropist, pinkerton, bully, etc. are not significant units of Italian, French, English, German, and other languages for a native speaker of Russian, having acquired the status of universal cultural formulas of universal significance. Nevertheless, in the Russian linguocultural space, for example, the name Bourbon, in contrast to the French linguoculture, where this eponym denotes an arrogant and rude officer, has a national expressive coloring and is used with the mark "contempt" for the determination of a rude, 
ignorant, uncultured, arrogant, and domineering man, often a domestic tyrant. It should be noted that Dobrodomov categorically refutes the connection with the anthroponym and insists on the version of the phonetic and contaminated transformation of French "barbon" - "starikaska" [5].

Anthropometaphors, the origin of which is associated with real persons or historical events, are of undoubted interest. Examples thereof are the words kondrashka, kondraty in independent use or included in the expression "kondrashka/kondraty grabbed" (determination of a huge scare) which is associated with the sudden violent death of Prince Dolgorukov from the ataman of the Bakhmut Cossacks Kondraty Bulavin in Peter's The First times - at the beginning of the 18th century.

An inexhaustible source of antonomasia is mythology. In Russian speech, the names of East Slavic mythological and fairy-tale characters are widely used in an appellative meaning: baba-yaga, kikimora, leshiy, lihoradka, solovey-rasboynik, chert, etc. These names have a pronounced national and cultural connotation. The metaphor of koschei is indicative in this series. It is included in the hyper-hyponymic series "old man": deduska, starik, starets, mafusail, muhomor, koschei, etc., being also the naming of elderly bosses. The name koschei is a stable metaphor based on the similarity with the East Slavic fairytale character. The appearance of the mythological Koschei traditionally in Russian consciousness resembles Death in a male guise. However, in the metaphorical name, there is no correlation with death, gloom. The similarities are associated with the skeletal body and longevity. At the same time, thinness is not a sign of a repulsive appearance. Vindictiveness, greed, avarice, and other features inherent in the mythological Koschei have not entered the modern semantics of the word. Nevertheless, one of the components of the meaning of the name is precisely the negative connotation, which is undoubtedly associated with the mythological roots of the metaphor. Koschei appears to be the embodiment of evil and manifests himself as a mythologically significant meta-sign for the opposition "good" - "evil" [6].

Russian dictionaries record both proper names and metaphorical lexical units that are universal metaphors from ancient mythology: Apollon/apollon, Gigant/gigant, Gerostrat/gerostrat, Gerkules/gerkules, Demon/demon, Satyr/ satyr, etc. The main metaphorical meaning is noted in the words adonis, narciss, goliath, ispolin, prometey. Anthroponyms of biblical characters are included in the fund of general knowledge. They have passed into appellatives, which acquire semantics similar in one or several essential features to the fundamental principle: Cain, Judas, Apostle, Asp/Aspid, etc. There are metaphorical formations Antichrist, Lucifer, Satan, the devil, etc. with the original meaning of the seme "evil". The name Herod, which functions in Russian in the meaning of "fiend, tormentor", often in relation to a spouse, was also rethought, which also testifies to the national-cultural semantics of the word. The metaphorization of the biblical Asp is also clear, in a secondary sense determinating an insidious, cunning, evil person. The national and cultural connotation in a word is manifested by transferring the features of a mythological character to a person. The Asp in the Bible symbolizes a mortal mired in sins, or an ancient terrible poisonous snake that seduced Eve to taste the forbidden fruit, that is the devil. The point of view, according to which in the Russian language the word asp is synonymous with the word Judas, and they are used to denote anger and betrayal, is denied by dictionary definitions. Dictionaries do not record the functioning of the token meaning "traitor". So, "an aspid, an aspik is an evil person, a curmudgeon, a crafty koschei, a stingy person" (Dal), "aspid - 2) an insidious, cunning, evil person" (Efremova); "aspid - 1) an evil, harmful person; 2) a stingy person, a curmudgeon" (Evgenieva), etc. The modern asp is brought together with the biblical one by cunning and deceit, to some extent anger and 
harmfulness. However, such signs as stinginess, greed were not clear characteristics of the Christian character. Probably, in the Russian language, the metaphor has deeper roots. In Slavic mythology, the aspid - a winged serpent living high in the mountains or in the gloomy north - personified the external enemies of the Slavs, making devastating raids on villages due to greed and gluttony [7]. Russian dictionaries also contain lexical units that have lost connection with their ancestor at the level of perception of a modern native speaker, for example, mafusail - a long-liver, an ancient old man, etc. This correlation is restored only on the basis of historical or etymological analysis. It should be noted that despite the universal significance of such metaphors and the absence of a national cultural connotation, in a specific context and in the author's individual interpretation, they can acquire Russian national-cultural semantics, which confirms the connective theory of Ritchie's metaphorical interpretation [8,9].

One of the ways of antonomasia is the consonance of an anthroponym with functioning lexical units or elements in a particular linguistic system and the possibilities of its folk etymologization.

Extralinguistic factors played a major role in the formation and history of anthropometaphors. Sobolevsky pointed out that the word "pentyukh" came from the personal name of Panteley, Panteleimon, which was pronounced as Penteleimon [10]. The word pentyukh as a representative of common people with the meaning of "manish, sluggish, unruly person" was included in the Dictionary of the Russian Academy of 1793. In modern Russian, the shade "uneducated, ill-mannered, redneck" was added to the original meaning. Chernyshev believes, as Vinogradov [11], that the name Panteley Pentely was widespread in the lower social strata. Formations with an expressive suffix -uhare also productive in the anthroponyms of folk speech. Probably, the name Pentyukh underwent an ironic rethinking in consonance with the word "pen" (stump) in a direct and metaphorical meaning outside the national language, in a different social environment - in the petty nobility, clergy, bourgeoisie, in the educated upper circles of urban society. The common people anthroponym Pentyukh began to be perceived as a symbol of lack of culture, rudeness, served as an object of ridicule, and became a characteristic, contemptuous lexical unit [12]. The name Vanka, the original meaning of which is associated with the nickname of a cabman in pre-revolutionary Russia, functions in the Russian language in the same sense of "mannish, uneducated, ill-mannered person, redneck". The anthropometaphor of the olukh (fool) entered the Russian literary language from the living folk-colloquial speech. Vinogradov investigated this determination and traced the possible paths of its appearance [13]. The scientist records the opinions of researchers and highlights the anthroponymic version of the emergence of metaphorical education, pointing to the relevance, but requiring a thorough historical explanation and social motivation, of the theory of antonomasia of the personal proper name Eleutherius (Greek E $\lambda \varepsilon v \theta \varepsilon \dot{\varepsilon}\left(\mathrm{s}_{)}\right)>$Olepherius $>$Olefy $>$Olukh. The anthroponym is attested in the northern and western Russian monuments of Russian business writing from the 16th century. in a metaphorical common noun-characteristic meaning - "a fool, a simpleton, a stupid person" (in the Novgorod scribal books: Olukh tanner, Olukh sundress, etc.; the name Olukh in the Dvina letters).

Another way of the transition of an anthroponym into an appellative is the phonetic design of the onym, the sound image of a word that evokes certain emotions or associations in a Russian speaker [14].

Vivid examples of the rethinking of the anthroponym are many names beginning with "F" - a sound originally alien to East Slavic languages. So, Vinogradov, referring to Korsh, writes that anthroponyms beginning with " $F$ " often received contemptuous or abusive 
meanings: Fofan $<$ Feofan, Falla $<$ Falalei, Fetyukh $<$ Feotikh, etc. [15]. In the Dictionary of the Russian Academy (1794, part 6), the meaning of the names Falya, Fetyukh is given: "a disagreeable, stupid, hindsight person". Vinogradov traces the history of these appellative formations of anthroponyms, pointing out the relatively frequent use of these words in literary language.

With a synonymous meaning in the Dictionary of the Russian Academy (1822, part 5), the complex word "prostofilya" is recorded. The first part, according to Vinogradov, "correlates with a similar component in the words commoner, common people, vernacular, simple-heartedness", the second part is the anthroponym Filya (diminutive of Filat or Philip), which "in the noble serf life of the 17th-18th centuries was the typical name of a servant peasant. This name was considered common and was surrounded by an expression of disdain and contempt" [15]. This position is confirmed by Dal, who defines the word filatka as "a fool, day-dreamer" (Dal). In the dictionaries of the Russian language, the nomination of a simpleton has the meaning of "a stupid, unreasonable person, day-dreamer" (Ushakov), "stupid, poorly intelligent person, day-dreamer" (Ozhegov), "the one who is stupid, not intelligent, day-dreamer" (Efremova). The word mordophilya is formed based on the same principle, it is noted in the Dictionary of Vasmer in the meaning of "an arrogant person".

Lakoff and Johnson call the metaphor a fundamental feeling that helps to understand the world. The researchers based their theory of metaphor on the postulate: "Metaphor permeates our daily life, and not only language, but also thought and action. Our usual conceptual system, in terms of which we think and act, is metaphorical in nature" [1].

\section{Conclusion}

In conclusion, it should be noted that an anthropometaphor is an example of the reflection of reality in the inextricable link between language and culture, including its fullness with national and cultural specifics.

In the authors' opinion, based on the presented analysis of Russian anthropometaphors, it can be stated that the fragment of the linguistic picture of the world in its own way encodes the existing reality, vividly conveys national and cultural information, makes it possible to a certain extent to trace the peculiarities of a person's worldview and attitude, based on a mythological basis, on the peculiarities of everyday life and spiritual life of the Russian people.

\section{References}

1. J. Lakoff, M. Johnson, Metafory, kotorymi my zhivem [Metaphors we live by], in N.D. Arutyunova, M.A. Zhurinskaya (eds), Theory of Metaphors: Collected Works (Progress, Moscow, 1990)

2. V.A. Maslova, Lingvokulturologiya [Linguoculturology] (Akademiya, Moscow, 2001)

3. N.I. Tolstoi, Eshche raz o semantike imeni sobstvennogo [Once again about the semantics of a proper name], in Selected Works, 1, 395-396 (Yazyki russkoi kultury, Moscow, 1997)

4. I.E. Gerasimenko, Pochemu zhenshhiny ljubjat Dona Zhuana? (o semantike gendernyh predpochtenij) [Why do women love Don Juan? (on the semantics of gender preference)], in O.G. Vronsky (ed), Materials of the IV Regional Scientific-Practical Conference of Graduate Students, Applicants and Young Scientists "Research Potential 
of Young Scientists: A Look into the Future", 54-59 (Publishing house of TSPU named after L.N. Tolstoy, Tula, 2008)

5. I.G. Dobrodomov, Rus Speech, 1, 103-110 (2003)

6. S.S. Lagoshina, V.V. Chaplygina, Young Sci, 2, 65-66 (2017)

7. E.A. Grushko, Iu.M. Medvedev, Slovar slavjanskoj mifologii [Dictionary of Slavic Mythology] (Russkii kupets, Bratia slaviane, Nizhny Novgorod, 1995)

8. D. Ritchie, Metaph Symb, 19(4), 265-287 (2004)

9. D. Ritchie, Metaph Symb, 18(1), 49-53 (2003)

10. A.I. Sobolevsky, Voronezh Hist Archaeol Bul, 2, 31-34 (1921)

11. V.V. Vinogradov, Rus Lang School, 2, 54-67 (1947)

12. V.I. Chernyshev, Sat Lang Think, 3-4, 174-178 (1935)

13. V.V. Vinogradov, Prochtenija drevnerusskogo teksta i istoricheskie i jetimologicheskie kalambury [Readings of the Old Russian text and historical and etymological pun], in Selected Works. Lexicology and Lexicography, 285-287 (Moscow, 1977)

14. A.V. Superanskaia, Obshhaja teorija imen sobstvennyh [General theory of proper names] (Nauka, Moscow, 1973)

15. V.V. Vinogradov, Vsemirnaja istorija: Okolo 1500 slov i fraz i bolee 5000 slov, svjazannyh s nimi [Word History: Approximately 1500 Words and Phrases and over 5000 Words Associated with Them] (V.V. Vinogradov Russian Language Institute of the Russian Academy of Sciences, Moscow, 1999) 